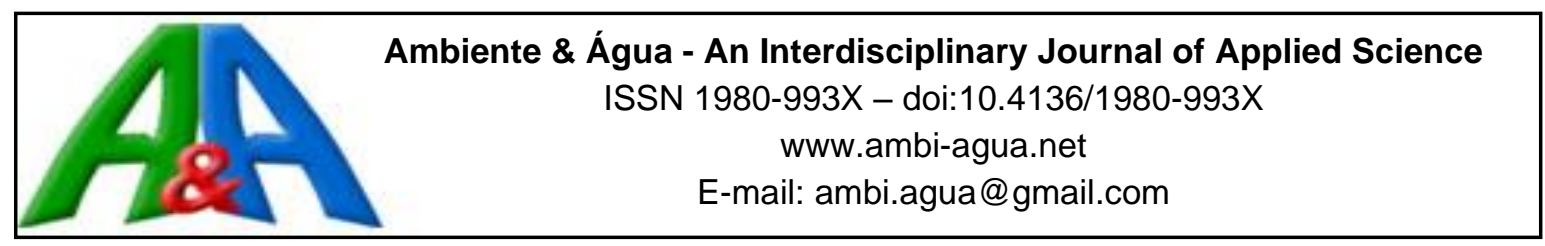

\title{
Sustainability assessment of sludge and biogas management in wastewater treatment plants using the LCA technique
}

\author{
ARTICLES doi:10.4136/ambi-agua.2371
}

Received: 30 Jan. 2019; Accepted: 25 Jun. 2019

\section{Karina Guedes Cubas do Amaral ${ }^{1 *}$; ; Miguel Mansur Aisse ${ }^{1}(\mathbb{D}$; Gustavo Rafael Collere Possetti ${ }^{2,3}$ (iD}

\footnotetext{
${ }^{1}$ Programa de Pós-Graduação em Engenharia de Recursos Hídricos e Ambiental (PPGERHA), Universidade Federal do Paraná (UFPR), Centro Politécnico, Bloco V, CEP 81531-990, Curitiba, PR, Brazil. E-mail: miguel.dhs@ufpr.br

${ }^{2}$ Programa de Mestrado Profissional em Governança e Sustentabilidade, Instituto Superior de Administração e Economia do Mercosul (ISAE), Avenida Visconde de Guarapuava, n² 2943, CEP 80010-100, Curitiba, PR, Brazil. E-mail: gustavo_possetti@yahoo.com.br

${ }^{3}$ Diretoria de Meio Ambiente e Ação Social, Gerência de Pesquisa e Inovação, Companhia de Saneamento do Paraná (SANEPAR), Rua Engenheiro Antônio Batista Ribas, $n^{\circ} 151$,

CEP 82800-130, Curitiba, PR, Brazil. E-mail: gustavo_possetti@yahoo.com.br *Corresponding author. E-mail: kacubas@gmail.com
}

\begin{abstract}
Upflow anaerobic sludge blanket reactors (UASBs) used in sewage treatment generate two useful byproducts: sludge and biogas. This study evaluated the sustainability of four different scenarios for the treatment and final destination of biological sludge and biogas in a mediumsized wastewater treatment plant (WWTP) in South Brazil. At this plant, the sludge is sanitized by Prolonged Alkaline Stabilization and applied to agriculture (base scenario). Scenario 1 is about biogas use to dry sludge, which is taken to be used in agriculture. In Scenarios 2 and 3 the heat of the sludge burning is used for drying and sanitation. Finally, in Scenario 3 the ashes are destined to landfills. An environmental impact assessment was performed through life-cycle assessment using the ReCiPe 2016 evaluation method. Social life-cycle assessment indicators, adapted and developed for WWTPs, were used for social assessment. Economic assessment was performed through the analysis of life-cycle costs. The dashboard of sustainability (DoS) method was used for global assessment of sustainability. For overall sustainability assessment, Scenario 1 had the highest score (678 points) (best scenario) in the DoS. The environmental dimension was what facilitated this scenario. For this dimension, the following indicators presented the highest points when compared to the other scenarios: soil acidification, ozone formation, terrestrial ecosystem. The base scenario had the lowest score (worst case scenario) (375 points).
\end{abstract}

Keywords: anaerobic reactor, life cycle assessment, wastewater treatment.

\section{Avaliação da sustentabilidade no gerenciamento do lodo e biogás, em estação de tratamento de esgotos, utilizando a técnica de ACV}

\section{RESUMO}

Reatores de manta de lodo anaeróbio de fluxo ascendente (UASB), usados no tratamento de esgoto, geram dois subprodutos que podem ser utilizados: lodo e biogás. O objetivo do 
presente estudo foi realizar a avaliação da sustentabilidade de quatro diferentes cenários de tratamento e destinação final do lodo biológico e biogás, numa Estação de Tratamento de Esgoto (ETE), de porte médio, localizada no Sul do Brasil. Nesta Estação o lodo é higienizado, pela Estabilização Alcalina Prolongada, e disposto na agricultura (cenário base). O cenário 1 corresponde a utilização do biogás para a secagem do lodo e este destinado na agricultura. Nos cenários 2 e 3, o calor da combustão do lodo é utilizado para a secagem e higienização, sendo no cenário 3, as cinzas destinadas para aterro. A avaliação dos impactos ambientais foi realizada através da avaliação do ciclo de vida, utilizando-se como método de avaliação o ReCiPe 2016. Para a avaliação social foram utilizados os indicadores da avaliação de ciclo de vida social, adaptados e desenvolvidos para ETEs, a avaliação econômica foi realizada através da análise dos custos do ciclo de vida. Para a avaliação global da sustentabilidade, foi utilizado o método Dashboard of sustainability. Com relação à avaliação global da sustentabilidade, o cenário 1 obteve a maior pontuação (678 pontos) (melhor cenário) no DoS. A dimensão que favoreceu esse cenário foi a ambiental, onde os indicadores de acidificação terrestre e formação de ozônio, ecossistema terrestre foram os indicadores que apresentaram uma pontuação mais elevada, em comparação com os demais cenários. O cenário base apresentou a menor pontuação (pior cenário) (375 pontos).

Palavras-chave: avaliação do ciclo de vida, estação de tratamento de esgotos, reatores anaeróbios.

\section{INTRODUCTION}

Population growth in Latin America and the Caribbean has exceeded the capacity of national and local governments to meet demand for water supply and sanitation (Noyola et al., 2012). New WWTPs, and the expansion of existing capacity and treatment level, should be designed to meet the needs of the sanitary sewage thus generated. As a consequence of this expansion, there has been increased generation of biological sludge and biogas. Approximately $30 \mathrm{~kg}$ of dry sludge/inhabitant.year (Hospido et al., 2010) and 10 to $28 \mathrm{NL}$ of biogas/inhabitant.year (Jesus Netto, 1936; Azevedo Netto, 1977; Duarte et al., 2018) is generated, with approximately $40 \%$ of biogas being lost together with effluent in stations using UASB anaerobic reactors (Nelting et al., 2017).

Treatment systems have the function of minimizing the environmental impacts of the release of effluents into the environment, but they themselves are an impacting element in the three dimensions of sustainability throughout their life cycle (Sanches, 2009). The adoption of sustainability criteria in the choice of the best technology for treatment and disposal of sludge should be taken into consideration (Hernandez-Padilla et al., 2017). A sustainable waste management system should be environmentally effective, economically accessible and socially acceptable (Noyola et al., 2013). In addition, it should be safe for workers and the community involved, with particular attention to the possibility of affecting the stakeholders involved (Padilla-Rivera et al., 2016).

Depending on the final destination adopted, biological sludge needs to be sanitized, with prolonged alkaline stabilization (PAS) being one of the techniques adopted in Brazil. In Paraná, Curitiba Metropolitan Region (RMC) is the main producer of sludge and it has been primarily destined for agriculture use (Bittencourt et al., 2014). According to Gutierrez et al. (2015), the potential impact related of using virgin lime for sanitizing sludge, in the route studied (sludge being sanitized by PAS and prepared for agriculture), signaled a demand for research on alternatives to lime in order to increase the credits of systems that choose to use sludge for agriculture use as a final destination.

Upflow sludge blanket reactor technology (UASB/RALF) is the second most-used in terms of the number of WWTPs in Brazil (Noyola et al., 2012; ANA, 2017), and represents $94.6 \%$ of 
the stations in existence in the state of Paraná in South Brazil (Ross et al., 2014). A characteristic of this technology is the generation of stabilized biological sludge and the generation of biogas rich in methane, the latter of which is still under-used for energy purposes in Brazil - currently most biogas generated in Brazilian WWTPs is burned by flare and emitted into the atmosphere.

Preliminary studies indicate that the treatment and management of biological sludge and biogas have a significant contribution in the calculation of environmental impact. In this sense, Amaral et al. (2016) carried out an environmental life-cycle assessment (LCA-environmental) of a medium-sized WWTP equipped with UASB reactors, and demonstrated that the processes of treatment and disposal of sludge and burning biogas in open flare together account for $44 \%$ of the contribution to the climate change category, $36 \%$ of the contribution to the depletion of the ozone layer category, $55 \%$ to human toxicity and $86 \%$ to terrestrial acidification.

Methodologies for the assessment of social impacts are still in the research phase or exist only as proposals in scientific articles. In 2004, the United Nations Environmental Programme (UNEP) recognized the need for social criteria in LCA and established a working group, which created the guide "Guidelines for Social Life Cycle Assessment of Products" (UNEP; SETAC, 2009). Another guide was released in 2010, divided by impact subcategories, to provide methodological help on how to create indicators and how to obtain data by source (UNEP; SETAC, 2013). The two documents are aimed at LCA-S for companies producing consumer goods. Recently, the Universidade Autônoma do México published an article suggesting social indicators linked to WWTPs (Padilla-Rivera et al., 2016). These authors used the stakeholders present in the guide and added five more indicators that they consider specific to WWTPs.

Regarding biogas and sludge sustainable managing, no studies were found that evaluate the integrated management of both sub products generated through UASBs reactors, using the technique of life cycle assessment. The studies are focused on environmental LCA and economic evaluation, or contemplate only biologic sludge management (Xu et al., 2014; Mills et al., 2014; Garrido-Baserba et al., 2015). Studies differ from each other when analyzing economic and environmental best options. In addition, none of the studies evaluated social dimension.

This study evaluates the sustainability (environmental, social and economic assessment) of different destination routes for biological sludge and biogas coming from anaerobic WWTPs, to support the selection of technologies to be used in future WWTPs and to assure the adequacy of those in existence.

\section{MATERIALS AND METHODS}

The investigated WWTP is located in South Brazil, has a capacity to treat $440 \mathrm{~L} \mathrm{~s}^{-1}$ of domestic sewage, and serves a population of 235,000 inhabitants. Preliminary treatment of sewage is provided by two mechanized screens, with $3 \mathrm{~mm}$ spacing, and a Dorr-Oliver type grit trap. For the biological stage of sewage treatment, the STS has six UASB reactors (secondary treatment) and two aerated facultative ponds (post-treatment). The biological sludge produced in the UASB reactors and in the aerated ponds is periodically discarded. The sludge is thickened (gravity thickener), dewatered in a centrifuge, subjected to prolonged alkaline stabilization (PAS) in the so-called Sludge Management Unit (SMU), and then destined for agriculture. The biogas generated by the UASB reactors is burned in open flare with an efficiency of approximately $50 \%$ (Kaminski et al., 2018).

The functional unit of the study is the management of byproducts - biological sludge and biogas - generated by treating $1 \mathrm{~m}^{3}$ of domestic effluent, and encompasses the phases of treatment and final destination. The reference flows are $0.052 \mathrm{Nm}^{3}$ of biogas captured at the top of the UASB reactor and $2.51 \mathrm{~kg}$ biological sludge obtained from the UASB anaerobic 
reactor $(\mathrm{TS}=2.6 \%)$. Methane dissolved in treated effluent $\left(8.5 \mathrm{mg} \mathrm{L}^{-1}\right)$ was also considered. The flows were obtained through a survey carried out in the studied wastewater treatment plant (WWTP) (between 2015 and 2017), which can treat up to $420 \mathrm{~L} \mathrm{~s}^{-1}$, and a pilot sludge drying system that processed $100 \mathrm{~kg} \mathrm{~h}^{-1}$ of wet sludge during 62 hours. The limits of the system, highlighting the case study and proposed scenarios, are presented in Figure 1.

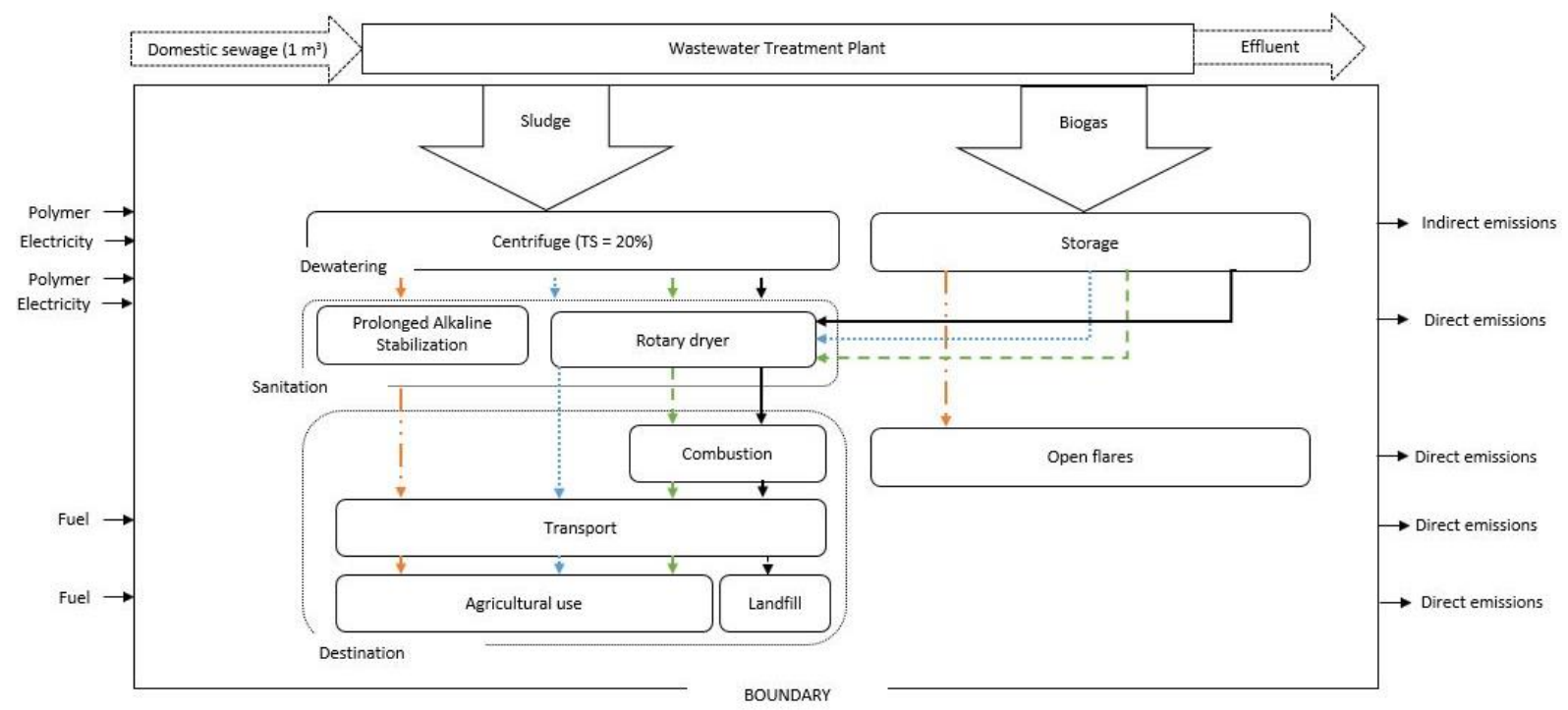

Figure 1. Scenarios for treatment and final disposal of sludge and biogas from WWTP.

Legend: Baseline Scenario $(-\rightarrow)$ : sludge is dewatered in the centrifuge, undergoes prolonged alkaline stabilization (PAS), and is destined for agricultural use, while biogas is destroyed in an open flare. Scenario $1(\cdots \rightarrow)$ : Biogas is used as a heat source to dry the sludge in a rotary dryer, and the dried sludge is used in agriculture. Scenario $2(--\downarrow)$ : Sludge is combusted and the heat generated is used to dry the dewatered sludge, while ashes are directed toward agriculture. Scenario $3(\rightarrow)$ ): Identical to Scenario 2, but ashes are discarded in the sanitary landfill.

The base scenario corresponds to the case study of studied WWTPs, wherein stabilized sludge is dewatered in a centrifuge and then submitted to PAS with virgin lime. The sanitized sludge is then sent to an agricultural destination while the biogas generated by the reactors is destroyed with low-efficiency open burners. Scenario 1 corresponds to the route where in generated biogas is used as a fuel source for drying and sanitizing sludge in a rotary dryer; the dried sanitized sludge is then sent to an agricultural destination. Scenario 2 corresponds to the route wherein sludge is combusted to produce heat used in the drying of sludge. Since the caloric value of sludge is not sufficient, a percentage of generated biogas is used. The resultant ashes are destined for agriculture. Scenario 3 is similar to Scenario 2, except the ashes are disposed in a sanitary landfill.

The methodology used to perform this work was based on the LCA and associated evaluations (LCC, S - LCA and LCSA).

The flow chart with the descriptions of the study steps is presented in Figure 2.

\subsection{Environmental assessment}

To develop the environmental inventory, the mass flow of the WWTP for the years 2015 and 2016 was determined. Energy flow was mapped by surveying equipment potentials and hours of operation. Emissions due to the transportation of products consumed in the treatment of sludge and the destination of the sludge in agricultural areas were reported as a function of the tkm unit, which considers the amount transported (in tons) and the distance traveled round trip (in kilometers). Distances between chemical manufacturers and the plant and the average distance to receiving agricultural areas for the last four years were used. Emissions for the 
application of virgin lime for sanitization (losses of $\mathrm{N}$ and $\mathrm{C}$ expressed in $\mathrm{NH}_{3}$ and $\mathrm{CO}_{2}$ ) were calculated by the $\mathrm{N}$ and $\mathrm{C}$ contents in the sludge before applying the lime, adopting a value of $2.81 \%$ for $\mathrm{N}$ (Andreoli et al., 2014; Aisse et al., 2001) and 15\% for C (Ross et al., 2014). Emissions due to the application in agriculture followed the models presented by Nemecek and Schnetzer (2011).

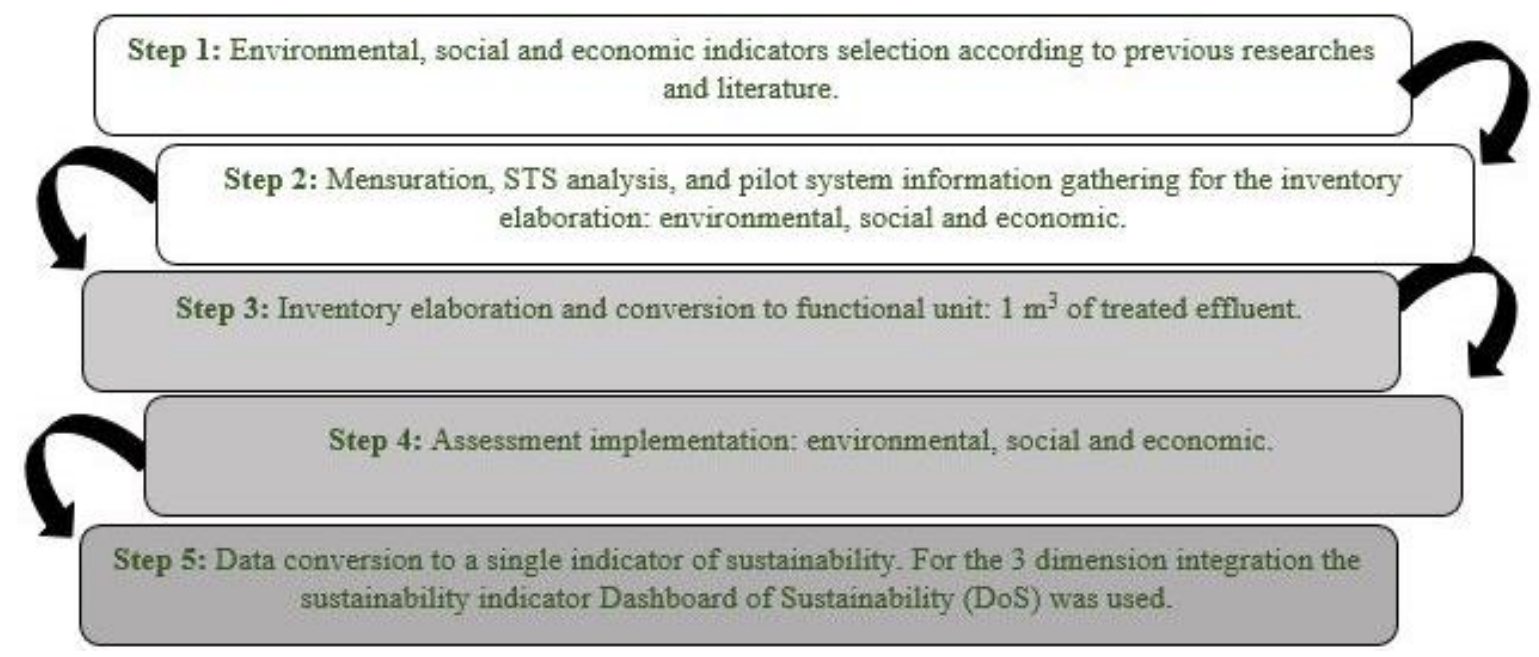

Figure 2. Steps of the research.

The environmental inventory for Scenario 1 was developed with data of the rotary dryer installed in a WWTP in South Brazil and presented by Possetti et al. (2015). The methodology for developing the inventory for the stages of centrifugation and agricultural application were the same as presented for the base scenario. In Scenario 2, the sludge is combusted with the ash destined for agriculture. The calorific value of dry biological sludge is $2,497.84 \mathrm{kcal} \mathrm{kg}^{-1}$ (Possetti et al., 2015). Scenario 3 is similar to Scenario 2 except that the ashes are destined for a sanitary landfill.

Calculation of the environmental impact used the Life-Cycle Assessment methodology and its two phases, by means of SimaPro 8.4 software. The ReCiPe 2016 Midpoint $(\mathrm{H})$ method was used in the present study. The categories of impacts evaluated were: global warming (GWP), stratospheric ozone depletion (ODP), ozone formation, terrestrial ecosystems (OF_TE), terrestrial acidification (TAP), freshwater eutrophication (FEP), terrestrial ecotoxicity (TETP), freshwater ecotoxicity (FETP) and human non-carcinogenic toxicity (HTPnc).

A pedigree matrix was used for analysis of uncertainty using a Monte Carlo simulation in the software. For this simulation, the standard deviation (SD) of each entry of the inventoried life-cycle was obtained by combining the pedigree matrix, a basic uncertainty matrix and the pedigree vector. The matrix considers two types of uncertainty parameters: intrinsic variability and uncertainty due to imperfect data usage. This is due to the use of estimated results without time and spatial extrapolation verification or to the use of different technologies (Muller et al., 2014). The considered indicators are reliability, completeness, temporal correlation, geographical correlation and further technological correlation.

Details of the environmental assessment and its results are presented in Amaral et al. (2018a).

\subsection{Social assessment}

The following categories of stakeholders were considered in the development of the social inventory: workers, consumers and the local community and society (UNEP; SETAC, 2009). Indicators were selected for each subcategory as suggested by UNEP and SETAC (2013) and the study of Padilla-Rivera et al. (2016), who presents the main social aspects associated with 
wastewater treatment. In order to produce a consistent method for all subcategories the methodology establishes a baseline for assessing the organization's profile called the basic requirement $(\mathrm{BR})$.

For monitoring and mapping odor, the concentration of $\mathrm{H}_{2} \mathrm{~S}$ was measured at certain points of the WWTP and in its vicinity using a portable meter. Measurements of $\mathrm{NH}_{3}$ were made on the day that the anaerobic sludge was being limed in the SMU. Occupation noise values were provided by the sanitation company that operates the studied STS in relation to the base scenario. For the other scenarios, measurements were taken in the pilot system of the rotary dryer installed. An adaptation of the methodologies described by Ramirez et al. (2014), Zortea et al. (2017) and Padilla-Rivera et al. (2016) was used for the assessment of social impacts.

Details of the social assessment methodology are presented in Amaral et al. (2017).

\subsection{Life-cycle cost analysis - LCC}

The economic inventory was performed by the life-cycle cost analysis (LCC) method. The method is based on the life-cycle assessment, but considers economic costs rather than environmental impacts. Costs related to the consumption of energy, chemicals, workers, equipment acquisition and maintenance were applied to the WWTP described in the base scenario and the other scenarios.

Total Cost (TC) was calculated for each alternative process analyzed as the sum of all annual acquisition, operation and maintenance costs. The cost of transport and the fuel used in the final destination of biological sludge was also considered in TC.

After the annual cost survey, the values were converted to the functional unit - the treatment and management of by-products to treat $1 \mathrm{~m}^{3}$ of effluent.

Details of the economic analysis and its results are presented in Amaral et al. (2018b).

\subsection{Assessment of the three dimensions of sustainability}

The next step was to convert the data into a single sustainability indicator. The sustainability indicator Dashboard of Sustainability (DoS), introduced by Traverso et al. (2012) (UNEP; SETAC, 2011) was used to integrate the three dimensions of sustainability. The model weights all indicators for the same scale and represents them in mathematical or graphical form. From this a score between 0 and 1000 points is determined, with zero points for the worst case possible and 1000 points for the best. Intermediate cases are then calculated using linear interpolation between these two delimitations, as presented in the Equation 1:

$$
(\text { DoS score })_{i}=1000 \times \frac{\left[(\text { value })_{i}-(\text { value })_{0}\right]}{\left[(\text { value })_{1000}-(\text { value })_{0}\right]}
$$

In which:

$($ DoS score $)=$ the DoS score assigned to the indicator in a context $\mathrm{I}$;

(value) $\mathrm{i}=$ indicator value for context $\mathrm{i}$ (intermediate);

(value) $0=$ indicator with the worst value among all contexts;

(value) $1000=$ indicator with the best value among all contexts.

This indicator works with a scale of 7 to 9 colors that correspond to different levels of sustainability. This color scale ranges from dark green (excellent) to deep red (critical) (Figure $3)$. In the final presentation, a ring is visualized where the external three circles present the indicators of the dimensions (environmental, social and economic) in a single measurement while the central circle presents the final sustainability index (SI or SID).

Environmental, social and economic dimensions were used for this work for a total of 23 
indicators, selected according to previous studies (Amaral et al., 2016) and literature (PadillaRivera et al., 2016; Anabestani e Zareie, 2017; Iftekhar et al., 2018; Xu et al., 2014; Mills et al., 2014; Garrido-Baserba et al., 2015) of which eight were environmental, 10 social and five economic (Table 1). Inventory details (environmental, social and economic) with the considered variables for each indicator is in an additional material.

\begin{tabular}{|c|c|c|}
\hline Color Scale & Degree of Sustainability & Point interval \\
\hline & Excellent & $889-1000$ \\
\hline & Very good & $778-888$ \\
\hline & Good & $667-777$ \\
\hline & Reasonable & $556-666$ \\
\hline & Medium & $445-555$ \\
\hline & Bad & $334-444$ \\
\hline & Very bad & $223-333$ \\
\hline & Severe attention & $111-222$ \\
\hline & Critical state & $0-110$ \\
\hline & No data & ---- \\
\hline
\end{tabular}

Figure 3. Color scale used in DoS software.

Table 1. Indicators considered in the present study for the evaluation of sustainability.

\begin{tabular}{lll}
\hline Environmental & Social & Economic \\
\hline Global warming & Wages paid to workers & Cost of dewatering stage (centrifuge) \\
Stratospheric ozone depletion & Noise level (workers) & Cost of sanitization system \\
Terrestrial ecosystem ozone formation & Use of hazardous chemicals & Cost of sludge disposal \\
Terrestrial acidification & Odor emission $\left(\mathrm{H}_{2} \mathrm{~S}\right.$ and $\mathrm{NH}_{3}$ ) (workers) & Cost of biogas disposal \\
Aquatic eutrophication & Biological risks (bacteria, fungi, viruses) & Maintenance cost \\
Terrestrial ecotoxicity & Sludge N and P content & \\
Freshwater ecotoxicity & Values of pathogens present in sludge & \\
Non-carcinogenic human toxicity & Noise level (community and society) & \\
& Odor emission (community and society) & \\
& Capacity to generate employment & \\
\hline
\end{tabular}

After the environmental, social and economic evaluation, the DoS model was used to interpret the three dimensions for the four scenarios.

\section{RESULTS AND DISCUSSION}

The results for the environmental, social and economic indicators are presented in Table 2.

Table 3 and Figure 4 present the results of the sustainability indicators. The arrow shows the position of the sustainability index in the color scale. The degree of sustainability of each dimension is also demonstrated through the color scale.

On the base scenario, the environmental dimension was the worst with the categories of climate change, terrestrial ecotoxicity, stratospheric ozone depletion, freshwater ecotoxicity and non-carcinogenic human toxicity being "very poor" on the scale. The steps that most contributed to the climatic change category was the emission of methane and carbon dioxide through biogas destruction in open burners $(56.13 \%)$, and by the emission of dissolved methane on the effluent (36.75\%). Houillon and Jolliet (2005) did en environmental LCA (Life Cycle

\section{IPABH}

Rev. Ambient. Água vol. 14 n. 5, e2371 - Taubaté 2019 
Assessment) (climatic changes category) to destine sludge and concluded that agriculture and landfill destination were the most outrageous for the category of climatic changes. Out of these, incineration was the best option. The high value of human toxicity is due to heavy metals existing in sludge and spread by agriculture use, also evidenced by Tarantini et al. (2007). Hospido et al. (2010) studied the reuse of anaerobic reactor sludge in agriculture in Spain. The results suggest that emergent pollutants' contribution is less important than heavy metals. The indicators that presented the worst scale for the economic dimension were: maintenance cost, disposal of sludge cost and disposal of biogas cost. Biological risk was the worst indicator for the social dimension, as a result of thermo tolerant coliforms presence in biologic sludge and the biologic risk intrinsic in manual sludge manipulation.

Table 2. Results for the indicators considered in the present study for sustainability assessment.

\begin{tabular}{|c|c|c|c|c|}
\hline & BS & S1 & S2 & S3 \\
\hline \multicolumn{5}{|c|}{ Environmental Indicators } \\
\hline GWP (kg de CO2eq.) & 0.7864 & 0.4409 & 0.4325 & 0.4598 \\
\hline ODP (kg de CFC-11 eq.) & $7.94 \times 10^{-08}$ & $3.88 \times 10^{-08}$ & $3.43 \times 10^{-08}$ & $3.09 \times 10^{-08}$ \\
\hline OF_TE (kg NOx eq.) & $1.39 \times 10^{-04}$ & $7.58 \times 10^{-05}$ & $2.89 \times 10^{-04}$ & $2.96 \times 10^{-04}$ \\
\hline TAP $\left(\mathrm{kg}\right.$ de $\left.\mathrm{SO}_{2}\right)$ & 0.0033 & 0.0007 & 0.0059 & 0.0048 \\
\hline FEP (kg de Peq.) & $1.34 \times 10^{-05}$ & $1.41 \times 10^{-05}$ & $1.39 \times 10^{-05}$ & $1.43 \times 10^{-05}$ \\
\hline TETP (kg de 1,4 DBeq.) & $5.3 \times 10^{-05}$ & $1.44 \times 10^{-05}$ & $2.47 \times 10^{-07}$ & $3.69 \times 10^{-06}$ \\
\hline FETP (kg de 1,4 DBeq) & $9.65 \times 10^{-05}$ & $1.62 \times 10^{-05}$ & $4.06 \times 10^{-06}$ & $1.12 \times 10^{-05}$ \\
\hline HTPnc (kg de 1,4 DBeq.) & 14.3482 & 0.1029 & 0.0642 & 0.0715 \\
\hline \multicolumn{5}{|c|}{ Social Indicators } \\
\hline Wages paid to workers & 4 & 4 & 4 & 4 \\
\hline Noise level (workers) & 3 & 3 & 3 & 3 \\
\hline Use of hazardous chemicals & 3 & 3 & 3 & 3 \\
\hline Odor emission $\left(\mathrm{H}_{2} \mathrm{~S}\right.$ and $\left.\mathrm{NH}_{3}\right)$ (workers) & 3 & 3 & 3 & 3 \\
\hline Biological risks (bacteria, fungi, viruses) & 2 & 3 & 3 & 3 \\
\hline Sludge $\mathrm{N}$ and $\mathrm{P}$ content & 3 & 3 & 4 & 0 \\
\hline Values of pathogens present in sludge & 3 & 3 & 4 & 0 \\
\hline Noise level (community and society) & 2 & 2 & 2 & 2 \\
\hline Odor emission (community and society) & 3 & 3 & 3 & 3 \\
\hline Capacity to generate employment & 4 & 3 & 3 & 3 \\
\hline \multicolumn{5}{|c|}{ Economic Indicators } \\
\hline Dewatering stage cost & 0.0237 & 0.0237 & 0.0237 & 0.0237 \\
\hline Sanitization system cost & 0.021254 & 0.075414 & 0.085121 & 0.085121 \\
\hline Sludge disposal cost & 0.006539 & 0.003024 & 0.001754 & 0.002135 \\
\hline Biogas disposal cost & 0.000125 & 0 & 0 & 0 \\
\hline Maintenance cost & 0.010007 & 0.004528 & 0.006153 & 0.006153 \\
\hline
\end{tabular}

Rev. Ambient. Água vol. 14 n. 5, e2371 - Taubaté 2019 
Table 3. Score for each dimension and the sustainability index for each of the studied scenarios.

\begin{tabular}{lcccc}
\hline Scenarios/Dimension & Environmental & Social & Economic & Sustainability index \\
\hline Base Scenario & 277 & 550 & 300 & 375 \\
Scenario 1 & 813 & 550 & 673 & 678 \\
Scenario 2 & 656 & 600 & 633 & 629 \\
Scenario 3 & 624 & 400 & 619 & 547 \\
\hline
\end{tabular}

NOTE: Base scenario = sludge sanitized by PAS and destined for agriculture, biogas destroyed by low efficiency burning; $\mathrm{S} 1$ = Scenario 1 sludge sanitized in rotary dryer using biogas and destined for agriculture; $\mathrm{S} 2=$ Scenario $2=$ sludge sanitized in rotary dryer through the heat from sludge combustion, with the ashes destined for agriculture; $\mathrm{S} 3=$ Scenario $3=$ similar to Scenario 2 but ashes destined for sanitary landfill.

On the ozone formation category (terrestrial ecosystems), Scenarios $2\left(2.89 \times 10^{-04} \mathrm{~kg} \mathrm{NO}_{\mathrm{x}}\right.$ eq) and $3\left(2.96 \times 10^{-04} \mathrm{~kg} \mathrm{NO}_{\mathrm{x}}\right.$ eq) have a high impact potential when compared to the base scenario $\left(1.39 \times 10^{-04} \mathrm{~kg} \mathrm{NO}_{\mathrm{x}}\right.$ eq). These scenarios were higher because of the increase of $\mathrm{NO}_{\mathrm{x}}$ emissions during sludge combustion; in Scenario 2, this step was responsible for $99 \%$ and $97 \%$ in Scenario 3.

Scenario $1\left(6.78 \times 10^{-04} \mathrm{~kg} \mathrm{SO} 2 \mathrm{eq}\right)$ presented a reduction of $79 \%$ of the potential environmental impact for the category of soil acidification when compared to the base scenario $\left(3.26 \times 10^{-03} \mathrm{~kg} \mathrm{SO}_{2} \mathrm{eq}\right)$. Sludge sanitation is the step that most contributed to this category. In the base scenario, this step was responsible for $72 \%$ of the total impact. $\mathrm{NH}_{3}$ emissions during sludge liming had the greatest impact on this category, representing $70 \%$ of the total impact. In Scenarios 2 and 3, sludge combustion represented $78 \%$ and $95 \%$ of the total impact, respectively. The contributing elementary flows were nitrogen emissions and sulfur oxide combustion. Within it were $\mathrm{SO}_{\mathrm{x}}$ emissions, representing $57 \%$ of environmental impact for this category in Scenario 2 and 70\% in Scenario 3.

Wang et al. (2013) studied options for sludge destination and treatment and the conclusion was that the best environmental option was combustion followed by co-incineration and landfill, although heavy metal emissions were not considered.

The bad performance of the category of employment-generation capacity in the social dimension, in Scenarios 1, 2, and 3, is by reason of using a rotating dryer for the sanitation and drying of biological sludge, increasing the level of mechanization and generating fewer jobs.

Regarding the economic evaluation, the elevated cost in Scenarios 1, 2, and 3 is due to the biologic sludge sanitation step, with the drying equipment acquisition being more than $50 \%$.

As shown in Table 3 and Figure 4, Scenario 1 had the best score (darker green coloration). The environmental dimension favored this scenario, with the indicators of terrestrial acidification and terrestrial ecosystem ozone formation having higher scores than in the other scenarios. The lowest score was for the base scenario for the category of terrestrial acidification due to the emission of $\mathrm{NH}_{3}$ during the process of sludge liming, and Scenario 2 and Scenario 3 due to the emission of $\mathrm{SO}_{\mathrm{x}}$ from the combustion of anaerobic sludge. Scenario 2 and Scenario 3 also had the lowest scores for terrestrial ecosystem ozone formation due to increased $\mathrm{NO}_{\mathrm{x}}$ emissions during sludge combustion.

The sustainability index for Scenario 1 was 678 points ("good" on the DoS scale). None of the three dimensions were "bad" on the scale. The social dimension scored 550 points ("average" on the scale), with the worst indicator being the capacity to generate employment. The worst indicator for the economic dimension was the sanitization stage, while for the environmental dimension it was freshwater eutrophication. The best indicators in the environmental dimension were the categories of climate change, terrestrial ecosystem ozone formation, human toxicity and terrestrial acidification. The best indicators for the economic 
dimension were maintenance cost and biogas disposal cost, while the best indicator for the social dimension was biological risks.

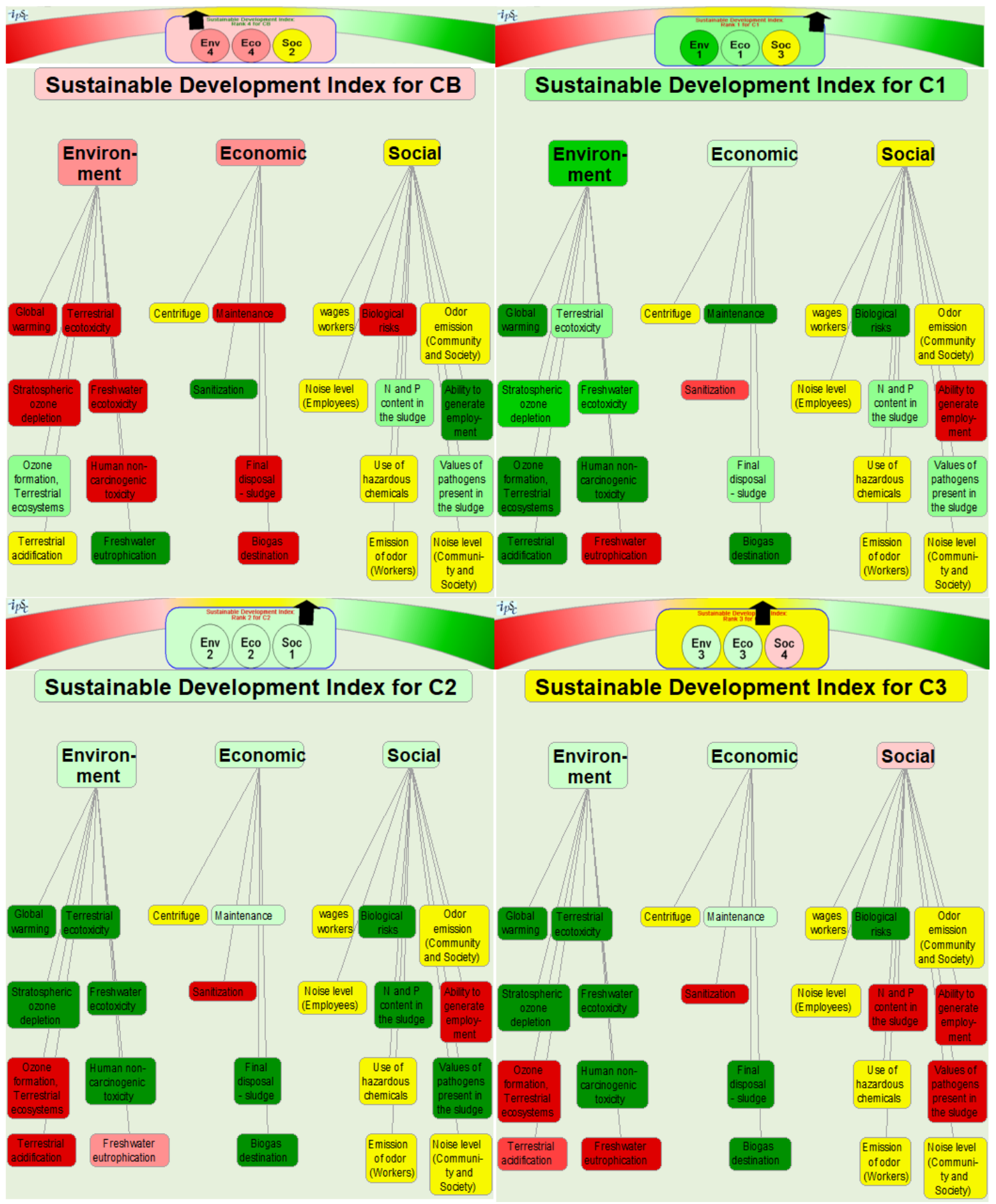

Figure 4. Results for sustainability indicators for the different scenarios *.

*NOTE: $\mathrm{CB}=$ base scenario (sludge sanitized by PAS and destined for agriculture, biogas destroyed by low efficiency burning). $\mathrm{C} 1=$ Scenario 1 (sludge sanitized in rotary dryer using biogas and destined for agriculture). $\mathrm{C} 2=$ Scenario 2 (sludge sanitized in rotary dryer through heat from sludge combustion, with the ashes destined for agriculture. C3 = Scenario 3 (similar to Scenario 2 but ashes destined for landfill).

Scenario 2 had a sustainability index of 629 points ("reasonable" on the DoS scale). The level of sustainability was the same for the three dimensions. The indicators with the lowest indexes in the environmental dimension were: terrestrial ecosystem ozone formation and 
terrestrial acidification. The stage with the lowest index in the economic dimension was sanitization system cost while the capacity to generate employment was the lowest for the social dimension.

Scenario 3 had a sustainability index of 547 points. The social dimension had the lowest score (400 points), where the indicators of sludge $\mathrm{N}$ and $\mathrm{P}$ content, capacity to generate employment and values of pathogens present in the sludge were the indicators that were "bad" on DoS scale. The worst indicators for the environmental dimension were terrestrial ecosystem ozone formation, terrestrial acidification and aquatic eutrophication. For the economic dimension the sanitization system cost had the lowest score. The best indicators for the environmental dimension were the categories of climate change, terrestrial ecotoxicity, stratospheric ozone depletion, freshwater ecotoxicity and human toxicity. The best indicators for the economic dimension were sludge disposal cost and biogas disposal cost, while the best indicator for the social dimension was biological risk.

Scenario 2 had the second-best score, being scaled as "reasonable". This scenario had a better index in the social dimension than did Scenario 1, due to it having higher $\mathrm{N}$ and $\mathrm{P}$ concentrations in the ashes of the biological sludge.

Scenario 3 had a lower score than the other scenarios because of the social dimension, which was due to non-utilization of the agronomic potential of the biological sludge. Thus, the final "rank" for the sustainability index was (from best to worst): Scenario 1, Scenario 2, Scenario 3 and Base Scenario.

\section{CONCLUSIONS}

The sustainability indicator Dashboard of Sustainability (DoS), used to integrate the three dimensions of sustainability, proved to be an important instrument for full display of the dimensions used.

Scenario 1, in which biogas is used for drying sludge that is destined for agriculture, obtained the highest score (best scenario) in the DoS. The environmental dimension favored this scenario, with the indicators of terrestrial acidification and terrestrial ecosystem ozone formation being the indicators that had higher scores compared to the other scenarios. Scenario 2 (sanitization of sludge by rotary dryer, through sludge combustion, and ashes used in agriculture) was the second best, with a better index in the social dimension than Scenario 1 due to higher $\mathrm{N}$ and $\mathrm{P}$ content in the ashes of the biological sludge. Scenario 3 (similar to Scenario 2, but ashes are destined for landfill) had a lower score in comparison to the other scenarios because of the social dimension due to non-utilization of the agronomic potential of biological sludge.

\section{ACKNOWLEDGEMENTS}

The authors would like to acknowledge the support obtained from the following Brazilian institutions: Coordenação de Aperfeiçoamento de Pessoal de Nível Superior - CAPES; Instituto Nacional de Ciência e Tecnologia em Estações Sustentáveis de Tratamento de Esgoto - INCT ETEs Sustentáveis (INCT Sustainable Sewage Treatment Plants) e Companhia de Saneamento do Paraná - SANEPAR.

\section{REFERENCES}

AISSE, M. M.; FERNANDES, F.; SILVA, S. M. C. P. Aspectos tecnológicos e de processos In: ANDREOLI, C. V.; LARA, A. I.; FERNANDES, F. (org.) Reciclagem de biossólidos: transformando problemas em soluções. 2. ed. Curitiba: SANEPAR, 2001. p. 49-119. 
AGÊNCIA NACIONAL DE ÁGUAS (Brasil). Atlas esgotos: despoluição de bacias hidrográficas. Brasília, 2017.

AMARAL, K. G. C.; AISSE, M. M.; POSSETTI, G. R. C. Análise do custo de ciclo de vida inerente ao tratamento e destinação final do lodo biológico e biogás, provenientes de ETE que emprega reator UASB. In: SIBESA - SIMPÓSIO ÍTALO-BRASILEIRO DE ENGENHARIA SANITÁRIA E AMBIENTAL, 14., 18-20 jun. 2018, Foz do Iguaçu. Proceedings[...] Foz de Iguaçu: ABES, $2018 \mathrm{~b}$.

AMARAL, K. G. C.; AISSE, M. M.; POSSETTI, G. R. C. Avaliação dos impactos ambientais no tratamento anaeróbio de efluentes domésticos baseado na Análise de Ciclo de Vida: Estudo de caso no Brasil. In: CONGRESSO INTERAMERICANO DE ENGENHARIA SANITÁriA E AMBIENTAL, 35., 23-25 ago. 2016, Cartagena. Proceedings[...] Colômbia: AIDIS, 2016.

AMARAL, K. G. C.; AISSE, M. M.; POSSETTI, G. R. C.; PRADO, M. R. Use of life cycle assessment to evaluate environmental impacts associated with the management of sludge and biogas. Water Science and Technology, v. 77, n. 9, p. 2292-2030, $2018 \mathrm{a}$. https://doi.org/10.2166/wst.2018.146

AMARAL, K. G. C.; AISSE, M. M.; POSSETTI, G. R. C.; COSTA, F. J. O. G.; UGAYA, C. M. L. Análise de Ciclo de Vida Social inerente ao gerenciamento de lodo e de biogás em uma estação de tratamento anaeróbio de esgoto. In: CONGRESSO ABES/FENASAM, 2-6 out. 2017, São Paulo, Proceedings[...] São Paulo: Abes, 2017.

ANABESTANI, A.; ZAREIE, A. Assessment of the Social Impacts of Sewage Treatment Plant on Rural Quality of Life: A Case Study of Parkandabad Peripheral Villages Around Mashhad. Journal of Sustainable Rural Development, v. 01, 2017. https://dx.doi.org/10.29252/jsrd.01.02.149

ANDREOLI, C. V.; VON SPERLING, M.; FERNANDES, F. Lodo de esgotos: tratamento e disposição final. Belo Horizonte: Departamento de Engenharia Sanitária e Ambiental - UFMG; Companhia de Saneamento do Paraná, 2014. 444 p.

AZEVEDO NETTO, J. M. Aproveitamento do gás de esgotos. Revista DAE, v. 41, p. 15-44, 1977.

BITTENCOURT, S.; SERRAT, B. M.; AISSE, M. M.; GOMES, D. Sewage sludge usage in agriculture: A case study of its destination in the Curitiba Metropolitan Region, Paraná, Brazil. Water, air, and soil pollution, v. 225, p. 2074, 2014. https://dx.doi.org/10.1007/s11270-014-2074-y

DUARTE, O. A. H.; PAUlA, A. C. de; CANTÃO, M. P.; POSSETTI, G. R. C.; AISSE, M. M. Avaliação da Vazão de Biogás produzido em Reator Anaeróbio tipo UASB, mensurado por Medidores do Tipo Vórtex e Dispersão Térmica. In: SIMPÓSIO ÍTALO-BRASILEIRO DE ENGENHARIA SANITÁRIA E AMBIENTAL SIBESA,14, 18-20 jun. 2018, Foz do Iguaçu - PR. Proceedings[...] Foz de Iguaçu: ABES, 2018. p. 1 - 9.

GARRIDO-BASERBA, M.; MOLINOS-SENANTE, M.; ABELLEIRA-PEREIRA, J. M.; FDEZ-GÜELFO, L. A.; POCH, M.; HERNANDEZ-SANCHO, F. Selecting sewage sludge treatment alternatives in modern wastewater treatment plants using environmental decision support systems. Journal of Cleaner Production, v. 107, p. 410-419, 2015. https://doi.org/10.1016/j.jclepro.2014.11.021 
GUTIERREZ, K. G.; FERNANDES, M. A. O.; CHERNICHARO, C. A. L. ACV de dois sistemas simplificados de tratamento de esgoto: UASB+SAC E UASB+FBP. In: CONGRESSO BRASILEIRO DE ENGENHARIA SANITÁRIA E AMBIENTAL, 0408 out. 2015, Rio de Janeiro. Proceedings[...] Rio de Janeiro: ABES, 2015.

HERNÁNDEZ-PADILLA, F.; MARGNI, M.; NOYOLA, A.; GUERECA-HERNANDEZ, L.; BULLE, C. Assessing wastewater treatment in Latin America and the Caribbean: Enhancing life cycle assessment interpretation by regionalization and impact assessment sensibility. Journal of Cleaner Production, v. 142, p. 2140-2153, 2017. https://doi.org/10.1016/j.jclepro.2016.11.068

HOSPIDO, A.; CARBALlA, M.; MOREIRA, M.; OMIL, F.; LEMA J.; FEIJOO, G. Environmental assessment of anaerobically digested sludge reuse in agriculture: potential impacts of emerging micropollutants. Water research, v. 44, p. 3225 - 3233, 2010. https://doi.org/10.1016/j.watres.2010.03.004

HOUILLON, G.; JOLLIET, O. Life cycle assessment of processes for the treatment of wastewater urban sludge: energy and global warming analysis. Journal of Cleaner Production, v. 13, p. 287-299, 2005. https://doi.org/10.1016/j.jclepro.2004.02.022

IFTEKHAR, M. S.; BURTON, M.; ZHANG, F.; KININMONTH, I.; FOGARTY, J. Understanding social preferences for land use in wastewater treatment plant buffer zones. Landscape and Urban Planning, v. 178, p. 208-216, 2018. https://doi.org/10.1016/j.landurbplan.2018.05.025

JESUS NETTO, J. P. O gás dos esgotos. Revista DAE, v. 01, p. 51-53, 1936.

KAMINSKI, G. F.; WAGNER; L. G.; SILVA, F. O. M.; POSSETTI, G. R. C. Análise crítica acerca da aplicação de queimadores enclausurados em ETEs para destruição de biogás. In: SIMPÓSIO MAUI BRASIL-ALEMANHA, 3., 3-5 abr. 2018, Curitiba. Proceedings[...] Curitiba: SENAI; ABES-PR, 2018.

MILLS, N.; PEARCE, P.; FARROW, J.; THORPE, R. B.; KIRKBY, N. F. Environmental \& economic life cycle assessment of current and future sewage sludge to energy Technologies. Waste Management, v. 34, p. 185-195, 2014. https://doi.org/10.1016/j.wasman.2013.08.024

MUlLER, S.; LESAGE, P.; CIROTH, A.; MUTEL, C.; WEIDEMA, B. P.; SAMSON, R. The application of the pedigree approach to the distributions foreseen in ecoinvent v3. International Journal of Life Cycle Assessment, v. 21, p. 1327-1337, 2014. https://doi.org/10.1007/s11367-014-0759-5

NELTING, K.; TRAUTMANN, N.; CAICEDO, C.; WEICHGREBE, D.; ROSENWINKEL, K. H.; COSTA, F. J. O. G.; POSSETTI G. R. C. Constraints on the dissolved methane in the effluent of full scale municipal UASB reactors. In: IWA LEADING EDGE CONFERENCE ON WATER AND WASTEWATER TECHNOLOGIES, 14., 29 maio-02 jun. 2017, Florianopolis. Proceedings[...] Florianópolis: IWA, 2017.

NEMECEK, T.; SCHNETZER, J. Methods of assessment of direct field emissions for LCIs of agricultural production systems. Zurich, 2011.

NOYOLA, A.; MORGAN-SAGASTUME, J. M.; GÜERECA, L. P. Selección de tecnologías para el tratamiento de aguas residuales municipales. 1. ed. México, 2013. 140 p.

Rev. Ambient. Água vol. 14 n. 5, e2371 - Taubaté 2019 
NOYOLA, A.; PADILLA-RIVERA A.; MORGAN-SAGASTUME, J. M. L.; GUERECA, L. P.; HERNANDEZ-PADILLA, F. Typology of Municipal Wastewater Treatment Technologies in Latin America. Clean-Soil, Air, Water, v. 40, n. 9, p. 926-932, 2012. https://doi.org/10.1002/clen.201100707

PADILLA-RIVERA, A.; MORGAN-SAGASTUME, J. M.; NOYOLA, A. M.; GUERECA, L. P. Addressing social aspects associated with wastewater treatment facilities. Environmental Impact Assessment Review, v. 57, p. 101-113, 2016. https://doi.org/10.1016/j.eiar.2015.11.007

POSSETTI, G. R. C.; RIETOW, J. C.; GERVASONI, R.; ALTHOFF, C. A.; CARNEIRO, C. Investigação experimental de um sistema piloto de secagem térmica de lodo movido a biogás. In: CONGRESSO BRASILEIRO DE ENGENHARIA SANITÁRIA E AMBIENTAL, 04-08 out. 2015, Rio de Janeiro. Proceedings[...] Rio de Janeiro: ABES, 2015.

RAMIREZ, P. K. S.; PETTI, L.; HABERLAND, N.T.; UGAYA, C. M. L. Subcategory assessment method for social life cycle assessment. Part 1: methodological framework. International Journal of Life Cycle Assessment, v. 19, p. 1515-1523, 2014. https://doi.org/10.1007/s11367-014-0761-y

ROSS, B. Z. L.; MARQUES, C. J.; CARNEIRO, C; COSTA, F. J. O. G.; FROEHNER, S.; AISSE M. M. Avaliação do impacto da incorporação de escuma em lodo de esgoto destinado a uso Agrícola. In: CONGRESSO INTERAMERICANO DE ENGENHARIA SANITÁRIA E AMBIENTAL, 34., 2-6 nov. 2014, México. Proceedings[...] México: Aidis, 2014.

SANCHES, A. B. Avaliação da Sustentabilidade de Sistemas de Tratamento de Esgotos Sanitários: Uma proposta metodológica. 2009. 278f. Tese (Doutorado em Recursos Hídricos e Saneamento Ambiental) - Instituto de Pesquisas Hidráulicas, Universidade Federal do Rio Grande do Sul, Porto Alegre, 2009.

TARANTINI, M.; BUTTOL, P.; MAIORINO, L. An environmental LCA of alternative scenarios of urban sewage sludge treatment and disposal. Thermal Science, v. 11, n. 3, p. 153-164, 2007. https://dx.doi.org/10.2298/TSCI0703153T

TRAVERSO, M.; FINKBEINER, M.; JØRGENSEN, A.; SCHNEIDER, L. Life Cycle Sustainability Dashboard. Journal of Industrial Ecology, v. 16, n. 5, p. 680-688, 2012. https://doi.org/10.1111/j.1530-9290.2012.00497.x

UNEP; SETAC. The Methodological Sheets for Subcategories in Social Life Cycle Assessment (S-LCA) Paris, 2013.

UNEP; SETAC. The Guidelines for social life cycle assessment of products. Paris, 2009.

UNEP; SETAC. Towards a Life Cycle Sustainability Assessment. Paris, 2011.

WANG, N.; SHIH, C.; CHIUEH, P.; HUANG, Y. Environmental Effects of Sewage Sludge Carbonization and Other Treatment Alternatives. Energies, v. 6, p. 871-883, 2013.

XU, C.; CHEN, W.; HONG, J. Life-cycle environmental and economic assessment of sewage sludge treatment in China. Journal of Cleaner Production, v. 67, p. 79-87, 2014. https://doi.org/10.1016/j.jclepro.2013.12.002

ZORTEA, R. B.; MACIEL, V. G.; PASSUELLO, A. Sustainability assessment of soybean production in Southern Brazil: A life cycle approach. Sustainable Production and Consumption, v. 14, p. 1-12-112, 2017. https://doi.org/10.1016/j.spc.2017.11.002 